\author{
世界のエネルギーと環境を巡る潮流 \\ (キーワード エネルギー展望, エネルギーと環境, 地球環境問題, 外部費用の内部化) \\ - 1993.11.1 受理-
}

財団法人世界エネルギー会議東京大会組織委員会 横 堀 惠 一

\section{1.まえがき}

産業革命以降の経済発展は, 石炭, 石油等の化 石燃料の利用を中心とするエネルギー消費の拡大 により支えられてきた。発展途上国や旧共産圈諸 国を含む世界経済の発展のためには，引続き，化 石燃料を中心とするエネルギー消費の拡大が必要 となる。増大するエネルギー消費は, 同時に, 化 石燃料資源の枯渴によって制約される，という懸 念が近年登場している。エネルギー問題としては, さらに, 化石燃料の賦存状況が地理的に偏り, 殊 に, 石油資源の中東地域への偏在が供給の安定性 を損なうとの懸念がエネルギー消費国の間で強く 認識されている。1973年の OAPEC による中東戦 争に際しての禁輸措置は, この懸念が現実化しう るとの認識を OECD 諸国をはじめとする石油消 費国に定着させた。

また, 産業革命以降の経済発展に伴う生産, 消 費活動の飛躍的拡大は, 人間活動のもたらす環境 への負荷を増し, 自然の回復能力を超え, 公害問 題等の環境問題を生んでいる。エネルギーの生産, 消費に伴う, 大気, 土壤, 水質等の環境污染の中, 殊に問題となるのは, 化石燃料の燃焼に伴う大気 污染である。化石燃料の燃焼に伴う硫黄酸化物, 擡素酸化物の大気への排出とそれによる健康被害 については，1960年代から対策が講じられてきた。 さらに, 最近は, 炭酸ガスの排出が気候変化をも たらす恐れがあると指摘されている。この気候変 動問題のような地球規模の環境問題は, 多くの場

専務理事事務局長

東京都港区虎の門 4-3-13 秀和神谷町ビル
合, 因果関倸が地理的, 時間的に拡大しているの で, 不確実性を伴う。他方, 取返しのつか媌被害 をもたらす可能性もある。化石燃料を中心とする エネルギー消費については，このように，環境面 からも制約を受けつつある。

そこで, 経済発展の必要性, 化石燃料の有限姓 およびエネルギー使用に伴う環境負荷の軽減とい う三つの課題を調和させることが, 世界のエネル ギー関係者の共通の課題となっている。本稿にお いては, このような状況を背景に, 今後の国際的 なエネルギー需給の展望, エネルギー問題と環境 問題の絡み合いおよび各国の対応のあり方につい て述べることとする。

\section{2. 世界的なエネルギー需給見通し}

将来のエネルギー展望は，常に不確実性を伴う。 特に, 最近の東欧圈に見られるような突然の政治 的変革等は, 予測可能ではなく, また将来の展望 にも影響を与える。従って, 将来のエネルギー展 望は, 一定の前提条件下での予測でしかありえな い。このため, 最近は, 「予測 “forecast”」と言 わずに,「シナリオ “scinario”」あるいは「展望 “outlook”」と言うのが一般的である。

このエネルギー展望については, 各種のものが ある中で, 最近, 相次いで国際エネルギー機関 (IEA) が「世界のエネルギー展望」(World Energy Outlook）（以下 IEA 展望」という。）を, 世界エネルギー会議がその「明日の世界のための エネルギー委員会」(WEC Commission “Energy for Tomorrow's World") の報告（以下「WEC 報 告」という) をそれぞれ公表した。本稿では，こ 
表 1 世界エネルギーの需給見通し

\begin{tabular}{|c|c|c|c|c|}
\hline & 199 & 0年 & 2010年 & 2020年 \\
\hline & WEC報告 & IEA展望 & IEA展望 & WEC報告 \\
\hline エネルギー需給 (GTOE) & 8.7 & 7.8 & 11.5 & 13.3 \\
\hline 構成比（\%) & & & & \\
\hline O E C D 諸国 & 47 & 53 & 46 & 35 \\
\hline 旧ソ連 · 東欧 & 20 & 21 & 15 & 14 \\
\hline その他 & 33 & 26 & 39 & 52 \\
\hline エネルギー種別 & & & & \\
\hline 構成比（\%) & & & & \\
\hline 固形燃料 & 26 & 29 & 29 & 24 \\
\hline 液体燃料 & 32 & 39 & 37 & 28 \\
\hline ガス燃料 & 19 & 22 & 24 & 21 \\
\hline 伸び率 $(1990=100)$ & & & & \\
\hline 固形燃料 & 10 & 00 & 144 & 139 \\
\hline 液体燃料 & & 00 & 132 & 132 \\
\hline ガス燃料 & & 00 & 130 & 165 \\
\hline 炭酸ガス排出量 $(G$ & ГC) & & & \\
\hline 全世界 & & .9 & 8.6 & 8.4 \\
\hline O E C D 諸国 & & .8 & 3.6 & 不明 \\
\hline 旧ソ連・東欧 & & .3 & 1.3 & 1.26 \\
\hline その他 ～ & & .75 & 3.7 & 不明 \\
\hline
\end{tabular}

出 所: WEC Energy for Tommorrow World (1993), IEA World Energy Outlook (1993) Gtoe $=10$ 億 $\mathrm{t}$ (原油換算 $)=10^{16} \mathrm{kcal}$ $\mathrm{GtC}=10$ 億 $\mathrm{t}$ (炭素換算)

の二つを対比させながら話を進めることとしたい。 両者共に，世界全体のエネルギー需給を扱い，か つ，広く世界的な規模で専門家の検討や参加を得 て，作成されているからである。IEA の展望は, 2010年，WEC 報告は，2020年までの将来を扱っ ている。両者の間には，WEC 報告では，非商業 エネルギーである薪等を含むこと，熱量換算方法 の差異等でデータが異なる。また，両方の経済成 長率の前提は地域別に差はあるが，WEC 報告の ほうが総じて少々高い。しかし，大体の趨勢を判 断するために用いるには，これ等の差異を概ね無 視しうる。また，両方の展望においても「基準 ケース」を採った。

いずれの展望においても，今後のエネルギー需 要は，途上国における伸びが先進国を上回り，20 〜30年後には，現在，世界エネルギー需要の約半 ばを占める OECD 諸国を上回ると想定される。 IEA 展望によれば，その割合は，1990年から2010
表 2 化石燃料の確認埋蔵量と埋蔵/生産比（RPR）

\begin{tabular}{lcccc}
\hline & \multicolumn{3}{c}{ 推定生産累計 } & 推定確認埋蔵量 埋蔵／生 \\
産比 & 1990年 GTOE & 1990年 GTOE & 年 \\
\hline 石 & 油 & 86 & 137 & 44 \\
ガ & ス & 40 & 108 & 57 \\
石 炭 & 不明 & 474 & 197 \\
褐 & 炭 & 不明 & 110 & 293 \\
\hline 出 & 所：WEC Energy for Tommorrow's World (1993)
\end{tabular}

年にかけて，OECD 諸国では53\%から $46 \%$ ，旧 ソ連・東欧圈では $21 \%$ から $15 \%$ に下がり，その他 の地域（殆どが途上国）において $26 \%$ から $39 \%$ に 上がる。WEC 展望においては，1990年のそれぞ れの割合が $47 \% ， 20 \% ， 33 \%$ か 2020 年の $35 \%$ ， $14 \%$ および $52 \%$ へ変化する，と想定されている （前述のように。WEC 展望には，途上国での使 用が多い非商業用エネルギーを含めるため, OECD 諸国の割合は，低くなる。）。

エネルギー種別の動向では，1990年水準に対し， IEA 展望では，2010年までに石炭44\%，石油33\% およびガス $66 \%$ の伸びとなり，WEC 報告では， 2020年までの伸びは，石炭39\%，石油 $32 \%$ および ガス $65 \%$ となる。両者共に, 今後20３0年間の工 ネルギー種別の需要の伸びをガスが最も大きく $60 \%$ 台，次いで石炭で約 $40 \%$, さらに石油で約 $33 \%$ と想定している。特に, 石炭の増加について は，旧ソ連・東欧圏では，消費が減退するが，そ れを上回る増加が途上国（特にアジア・太平洋） で起こると見込まれる。

このようなエネルギー需要の伸びは供給の制約 を受けるであろうか。WECの報告は，現在の確 認埋蔵量は, 2020年までの化石燃料の需要を賄う のに十分であるが，石油や天然ガスの賦存量は, 早く減少し, 価格上昇によって発見や開発が進ん でも，不可避的な減少の時期を遅らせるだけにす ぎない，としている(表2)。

しかし，化石燃料の埋蔵量が量的に需要量に見 合うことは，安定供給が確保されることを意味し ない。化石燃料の賦存状況は，地域的に限られ， 殊に石油の大半は, 政治的に不安定な中東地域存 在していることは周知の通りである。IEA 展望で は, OECD 諸国域内，特に，北海や北米の生産が 減少し続け，2010年には現在より約 2 百万バーレ ル／日減の13.8百万バーレル／日となり，旧ソ 
連・東欧圈の生産が当面低迷を続け，その後の回 復を見込んでも2010年は，1990年より低い10.6百 万バーレル／日にとどまり，中東およびベネズエ ラ以外は増産により，2010年は21.1百万バーレル /日が期待されるとしても, 中東およびベネズエ ラからの供給の期待量は1990年の19.3百万バーレ ル／日から2010年には44.6百万バーレル／日に増 加するとしている。WEC 報告では石油供給につ いての定量的な分析は示されていないが, エネル ギー供給の制約の強まりを認識し, 今後の産油地 域も厳しい気候条件, 海底等の地理的条件, 少な い埋蔵量等による限界費用の上昇を指摘している。 これに加えて, エネルギーの輸送, 配送について も, 輸送関連施設（パイプライン，港湾等）の拡 充が必要と認識し,さらにこれ等の供給側の要因 は, 様々な政治的, 経済的, 資金的, 制度的, 技 術的，環境的，時間的な制約の下に置かれている ことが指摘されている。

化石燃料需給に関わる上記の問題から, エネル ギー供給面において，原子力および再生利用エネ ルギー（太陽エネルギーを含む）の利用も重要な 課題となる。しかし, IEA 展望も, WEC 報告も, 量的には，これ等非化石燃料の利用が増加するも のの, エネルギー需給に占める比率は, 余り大き く変わらない, としている。IEA 展望は, 原子力 の現在の比重 $(6.7 \%)$ が2010年にはやや低下 (6\%) するとしている。WEC 報告は, 原子力 の一次エネルギー供給中の比率を現在の $5 \%$ から
2020年でも $6 \%$ へと僅かに増えるとしか見込んで いない。再生利用エネルギーについては, IEA 展 望では水力が $2.4 \%$ から $2.9 \%$ ，地熱その他が $0.4 \%$ から $1.2 \%$ へと増えるとしている。WEC 報 告は, 再生利用エネルギー全体が現在の $17 \%$ から 2020年に $21 \%$ の比率への上昇を見込んでいるが, その内，水力が $8 \%$ 弱（1990年 $6 \%$ 弱）で，伝統 的再生利用エネルギー (薪等) が10\%弱（同 $9 \%$ 強）で, 新型再生利用エネルギーと呼ぶ太陽, 風 力, 地熱, およびバイオマス, 海洋および小型水 力の役割は僅か $4 \%($ 同 $2 \%)$ としている (WEC 報告と IEA 展望とでは，上述のように熱 量換算等の差異があるので, 数值が一致しない。)。

さらに, エネルギー需給バランスの適正化には, エネルギー効率の進展が必要である。この点で, IEA 展望では, 主として輸送部門を除いては, エ ネルギー効率向上を期待せず，1990年から2010年 までの効率向上は僅か年率 $0.72 \%$ しか見达んでい ないが，WEC 報告では，年率1.8\%を見达んでい る。この点が, IEA展望の方がエネルギー需要の 高い伸びや後述のように $\mathrm{CO}_{2}$ 排出見达みも高めの 想定となった大きな理由と思われる。しかし，い ずれの想定が現実的かは，議論の余地がある。 WEC 報告自体認めているように, $1.8 \%$ という年 率の効率向上は，過去に比しても高い（表 3$) 。$ また, 近年の地球環境問題の気候温暖化の主因と される炭酸ガス $\left(\mathrm{CO}_{2}\right)$ の排出状況をみると, 1990年の全世界59億 $\mathrm{t}$ に対し, IEA 展望は, 2010

表3 エネルギーの集約度の変化率 (年率)

\begin{tabular}{|c|c|c|c|c|c|c|c|c|}
\hline & 1960 & 1965 & 1970 & 1975 & 1980 & 1985 & 1990 & 1990 \\
\hline & 1965 & 1970 & 1975 & 1980 & 1985 & 1990 & 2010 & 2020 \\
\hline \multicolumn{9}{|l|}{ WEC報告 } \\
\hline O E C D 諸国 & +0.2 & +0.1 & -1.3 & -1.6 & -1.8 & -1.7 & - & -1.9 \\
\hline 旧ソ連 - 東欧 & +0.1 & 0.0 & +0.3 & +0.9 & +0.2 & -0.5 & - & -2.1 \\
\hline その他 ～ & -0.6 & -2.3 & -0.8 & -0.4 & +0.2 & +0.1 & - & -1.7 \\
\hline 全世界 & \multicolumn{2}{|c|}{-0.25} & \multicolumn{2}{|c|}{-0.95} & \multicolumn{2}{|c|}{-0.91} & & -1.8 \\
\hline \multicolumn{9}{|l|}{ IEA展望 } \\
\hline O E C D 諸国 & \multicolumn{2}{|c|}{-} & \multicolumn{4}{|c|}{$-1.52^{(1)}$} & -1.00 & \\
\hline 旧ソ連・東欧 & \multicolumn{2}{|c|}{-} & \multicolumn{4}{|c|}{$+0.64^{(1)}$} & -0.60 & \\
\hline その他 & \multicolumn{2}{|c|}{-} & \multicolumn{4}{|c|}{$+1.11^{(1)}$} & -0.97 & \\
\hline 全世界 & \multicolumn{2}{|c|}{ - } & \multicolumn{4}{|c|}{$-0.53^{(1)}$} & -0.71 & \\
\hline
\end{tabular}

(注) (1)IEA 展望は、1971〜1990年の変化率

出 所：表 1 に同じ 
年で86億 $\mathrm{t}$ に達するとしているのに対し, WEC 展望では，2020年で84億 $\mathrm{t}$ とっと緩い上昇を見 込んでいる。いずれにしても，今後20－30年で $\mathrm{CO}_{2}$ の排出量が $40 \%$ 程度増えると見込まれる。こ れは，エネルギー消費に伴う環境污染がそれだけ 厳しくなることを示唆している，と考えられる。 WEC 報告では，伝統的な大気污染物質である $\mathrm{SO}_{\mathrm{X}}, \mathrm{NO}_{\mathrm{X}}$ の排出状況の想定を行っており, 地域 的に差が大きいが，全世界では， $\mathrm{SO}_{\mathrm{X}}$ が1990年の 64 百万t $\mathrm{t}$ か 2020 年の 67 百万 $\mathrm{t} へ 9 \%$ 増加し, $\mathrm{NO}$ x が 24 百万t から 27 百万 $\mathrm{t}$ へと $14 \%$ 伸びると想 定している。

以上の諸点から, 今後の世界経済の発展に伴い, 世界的にエネルギー需要も大きく伸長すること, 化石燃料の需要増も大きいこと, エネルギー供給 の安定面の懸念，価格上昇の恐れとともに，エネ ルギー利用に伴う環境負荷も増大することが示さ れる。また，発展途上国も経済発展により，世界 のエネルギー需要や環境負荷におけるその比重も 増大し，いずれ，先進国よりも重みを増すことも 示されている。

\section{3.エネルギーと環境}

エネルギー利用を始めとする人間活動は, 環境 に様々な負担を強いることが多い。エネルギー活 動については, 特に, 化石燃料の燃焼に伴う大気 污染が問題とされる。この他にもエネルギー活動 が係わる環境問題としては, 石油タンカー事故に よる海洋污染や原子力発電所の事故による放射能 污染等がしばしば議論される事例である。

化石燃料の燃焼に伴う大気污染としては, 従来 から媒塵, 硫黄酸化物 $\left(\mathrm{SO}_{\mathrm{X}}\right)$, 窒素酸化物 $\left(\mathrm{NO}_{\mathrm{x}}\right)$ 等の排出が問題とされてきたが，最近で は，気候温暖化をもたらす温室効果ガスの中で大 きな比重を占める炭酸ガス $\left(\mathrm{CO}_{2}\right)$ の排出が問題 とされている。気候温暖化のような地球規模の環 境問題の登場は, 従来の地域的な環境問題と, 次 のような点で異なり，対応を難しくさせる。

第 1 に，因果関係が空間的に拡がっている。越 境的な被害を持つと言いうる。原因が起こった場 所に限定されず，広い範囲で環境破壞が生じるこ とである。

第 2 に，因果関係が時間的に拡がっている。気 候温暖化も，炭酸ガス等の温室効果ガスの大気中
の濃度が高まって起きる, とされ, 原因から結果 までの時間的経過が長い。

このような地球環境問題の空間的，時間的な因 果関係の拡がりは，因果関係の不確実さを伴うと 同時に，取返しのつかない損害を生む可能性をも 持っている。このため, 他の面では無害である物 質も後で危険物とされる可能性もある。例えば, オゾン層を破壊するフロンの使用製造禁止も, 当 初は，無害の物質と考えられていたが，上空での 分解に伴うオゾン層破壞が検証されたために対応 等が採られている。気候温暖化問題についても， 炭酸ガスの温室効果は，一世紀前に知られていた が, 炭酸ガスの排出, 吸収のメカニズム, 気候変 化の影響についての解明が今でも完全ではない。 しかし，気候変化により取返しのつかない損害を 生ずる恐机もあるため，そのメカニズムの完全な 解明を待たずに，対応策をとることが求められて いる。その他の地球環境問題としては, 生物多様 性保護等がある。これらの環境問題の共通点には, また，在来の環境問題が身近かな健康被害を生む ものであるのに対し，対象が健康問題に比べて， 我々の生活への係り方が間接的であったり, 幅広 かったりするために, なかなか, その問題が理解 されがたい面もある。このために，対応策の費用 の負担を求められる側から，疑問を提起され易い 面もある。

地球環境問題をはじめとする環境問題の拡がり により，従来の環境問題との関係で，その影響や 対応策の面で相乗効果あるいは対立効果が生じる ことがある。例えば，地球温暖化との関係では， $\mathrm{SO}_{\mathrm{X}}$ や $\mathrm{NO}_{\mathrm{X}}$ 等の大気中の微粒子が泠却効果を持 つ，といわれる。他方， $\mathrm{SO}_{\mathrm{x}}, \mathrm{NO}_{\mathrm{X}}$ 等による酸性 雨が森林を破壊し，炭酸ガスの吸収を減らすこと も指摘される。フロンは，オゾン層破壊効果だけ でなく，温室効果も高いとされてきたが，オゾン 層破壊の結果，温室効果は緩和された，という指 摘もある。このように，環境対策を進めるに当っ ては，他の環境上の影響も総合的に，体系的に考 えて進めることが必要になってきている。この環 境問題間の相乗効果や対立効果について言えば, 例えば，上記の対立効果があるからといって， $\mathrm{SO}_{\mathrm{X}}$ や $\mathrm{NO}_{\mathrm{X}}$ の排出抑制が $\mathrm{CO}_{2}$ 排出抑制とさらに 矛盾する訳ではない。 $\mathrm{SO}_{\mathrm{X}}$ や $\mathrm{NO}_{\mathrm{X}}$ は，健康被害 
を生む有害物質である。さらにこれまでの IPCC 報告では, $\mathrm{SO}_{\mathrm{x}}, \mathrm{NO}_{\mathrm{x}}$ による健康被害は, 気候変化によって，覀化しうると指摘している。 フロンについても同様であるが，総合的に判断し， 環境問題に取り組む必要がある。

ところで環境問題が生じた原因は, 環境の保護 に必要な資源（労働力, 資金等も含む。）を我々 が用いなかったからである。何故そうなったか, といえば，物やサービスの生産，流通，消費の過 程でそのような資源の用い方をする仕組みがな かったからである。環境基準の設定等により, 環 境保全に資源を用いるようにさせることを，経済 学者は「外部性の内部化」という。外部性の内部 化は，通常，法令等の約束がなければ実現しない (よほど徳の高い人々の集まりは，別であろう が)。このような約束は，人々の納得，合意がな ければ成立しない。現実には，このため，環境基 準やその達成状況は, 国毎に異なる。

例えば，火力発電所における $\mathrm{SO}_{\mathrm{x}}, \mathrm{NO}_{\mathrm{x}}$ 排出 状況，無鉛化ガソリンの普及状況および現時点で の炭酸ガスの排出状況を先進国間で比べれば，日 本の達成状況は, 秀でている（表 4 ）。また，外

表 4 諸国のエネルギー関連環境水準

\begin{tabular}{|c|c|c|c|c|}
\hline & 日 本 & アメリカ & ドイツ & $\begin{array}{l}\text { スウェ } \\
\text {-デン }\end{array}$ \\
\hline \multirow{4}{*}{$\begin{array}{l}\mathrm{SO}_{\mathrm{x}} \text { 排出量 } \\
\text { 総排出量 } \quad[1000 \mathrm{t}] \\
\text { 一人当たり排出量 }[\mathrm{t}]\end{array}$} & & & & \\
\hline & 1,079 & 21,200 & 2,223 & 220 \\
\hline & 0.009 & 0.088 & 0.036 & 0.026 \\
\hline & (1983) & (1983) & (1983) & (1983) \\
\hline \multicolumn{5}{|l|}{$\mathrm{NO}_{\mathrm{x}}$ 排出量 } \\
\hline 総排出量［1000t] & 1,416 & 19,300 & 2,969 & 300 \\
\hline \multirow[t]{2}{*}{ 一人当たり排出量 $[t]$} & 0.012 & 0.080 & 0.049 & 0.036 \\
\hline & (1983) & (1983) & (1983) & (1983) \\
\hline \multirow{5}{*}{ 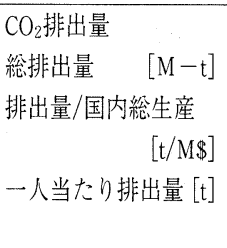 } & & & & \\
\hline & 299.2 & 1513.1 & 212.1 & 23.4 \\
\hline & 199.9 & 341.9 & 315.6 & 216.0 \\
\hline & 2.45 & 6.14 & 3.45 & 2.77 \\
\hline & (1983) & (1983) & (1983) & (1988) \\
\hline \multirow{3}{*}{$\begin{array}{l}\text { 無鉛ガソリン } \\
\quad[\% \text { 総販売量 }]\end{array}$} & & & & \\
\hline & 100 & & 65 & 46.2 \\
\hline & (1990) & (1989) & (1983) & (1983) \\
\hline
\end{tabular}

[ ] 単位 ( ) 年度

出所 : OECD Environmental Date, OECD Energy Balances 1988, Oil and Gas Journal
部費用の内部化が進んでいるか, 否かの一つの外 形判断材料は, エネルギー価格（税込み）である が, 総じて，日本は高く，これに反し，環境水準 の達成状況の低い米国等は低い。

地球環境問題等の登場で環境問題も新たな局面 を迎えている現在，伝統的な環境問題においてす ら，各国の対応が一様でない。不確実性等の伴う 地球環境問題への具体的な行動づくりへの合意に ついては，一層の難しさが伴う。また，伝統的公 害問題における対応の不揃いをその侭にして，炭 酸ガス排出抑制のみで共通手段，例えば一律の炭 酸税導入採ることは，非現実的である。日本の例 に見られるように， $\mathrm{SO}_{\mathrm{x}}, \mathrm{NO}_{\mathrm{x}}$ 排出が低いところ は, $\mathrm{CO}_{2}$ 排出も低い。 $\mathrm{SO}_{\mathrm{x}}, \mathrm{NO}_{\mathrm{x}}$ 対策のように, 脱硫，脱硝装置のような対応の利かない炭酸ガス 排出抑制は，エネルギーの効率化（燃焼の効率化 のみならず，末端エネルギー消費の効率化等も含 む。）または非化石燃料（ $\mathrm{SO}_{\mathrm{X}}, \mathrm{NO}_{\mathrm{X}}$ の排出量の 少ない天然ガスもこれに準ずる。）への転換しか 対応策がない。これは, $\mathrm{SO}_{\mathrm{X}}, \mathrm{NO}_{\mathrm{X}}$ 排出抑制策と して, 従来からも推進されている。この結果, 炭 酸ガス排出抑制を主眼としてこれ以上のエネル ギー効率化，非化石燃料転換を進める際は，他国 に比しコストの高いものとなると想定される。こ れは, 現に行われている各種の計量モデル試算で 日本の炭酸ガス抑制の限界費用が他国に比べ，高 いことにも示される。合意の得難い措置を一斉に 導入するよりも, より身近かで分かりやすい伝統 的公害対策において, 少なくとも先進諸国間で政 策調整を行い, 併せて炭酸ガス排出抑制も可能な 限度まで実行する方が現実的と考える。

外部費用の内部化については, さらに三点付け 加えたい。第一に, 外部費用の内部化の前提は, それの価格が市場で形成されで, 歪められていな いことである。しかし，エネルギー価格において は，途上国や社会主義圈のみならず，いわゆる西 側工業国に抢いても, 先頃まで, 生活必需物資的 性格, 社会政策的配慮, 公共独占性 (電力, ガ ス）等の理由から低水準に抑えたりして価格形成 が歪められている場合が多かった。最近は, エネ ルギー間競合，規制緩和等により，多くの価格が 市場原理に従うようになっているが，わが国でも 灯油価格が低水準に抑えられる等歪みが残ってい 
る。外国においては，産業用電力料金等での差別 価格も残っている。エネルギー価格の歪み是正は, 企業の体質強化のみならず，環境対策等の政策見 地からも重要な問題となっている。

第二に，内部化さるべき外部費用は，環境費用 のみではない。例えば，エネルギーの安定供給確 保のための費用である石油備蓄費用等がある。日 本における電源開発促進税, 石油税等の諸税は, このような内部化の例示である。これを外国と比 較すれば，かなりの高水準である。例えば，米国 では, 戦略石油備蓄（SPR）は，その費用を一般 的な税源である所得税, 法人税等からの歳入で 賄っている。わが国は石油税の形で石油消費に伴 う費用として捉えている。エネルギーに係わる外 部費用に関しては，国際的な合意形成により，一 定の基準が作成されれば，各国間制度の調和も図 れると考える。また，外部費用は，エネルギー消 費面だけでなく，生産から消費に至る全ての局面 で存在するので，これ等を総合的に捉える必要が ある。例えば，かって，天然ガスについては，採 掘, 輸送段階のメタン発生を考えれば，石炭より も環境を污すのではないか, と議論された。この 点については，天然ガスの方が生涯サイクルを分 析して総じて石炭よりも清潔である，とされてい る。例外としては, 旧ソ連では, 輸送段階のガス 漏れが大きく，よく管理された石炭よりも環境負 担が大きい，という意見もある。環境費用の内部 化もこのように総合的な見地から行われる必要が ある。

第三に，外部費用の内部化の手段である。環境 破壊の原因を生んでいる企業や消費者にその防止 または損害回復の費用を負担させるためにどのよ うな手段をとるか，の問題である。通常，措置と して採られることが多いのは，環境基準設定等の 規制，公害防止設備等への助成 (補助金) および 污染物質排出に対する課徴金である。一般的に， 規制は，明示的に環境保護水準を示したり，特定 の行為を禁止または奨励する点で直接的であるが, 運用面で規制当局の恣意が入ったり，あるいは硬 直化する恐れがある，とされる。補助金について は，完全に外部費用の内部化にならない（一部は, 政府が負担する）こと，補助金一般が市場で歪曲 機能を持つとの懸念から批判がある。しかし，現
実の補助金の多くは，費用の一部分を軽減するも の（例，低利融資，税制上の割増償却，特別償却 等) が多い。課徴金は，より市場経済に適合する が, 課徴金の水準, 賦課の方法等で環境保全目的 を達しうるように定めるのは難しい。以上の他, 最近は, 譲渡可能な排出許可証, 課徵金, 割戻金 の組み合わせ (“feebate”) 等が議論されている。

譲渡可能な排出許可証は排出許可量を割り当て た上で, 個別の過不足分の調整を当事者間の譲渡 融通により行うものである。排出許容量の範囲内 で, 排出者が裁量では排出源からの排出量を決定 し，過不足の市場での取引を通じ，最小費用での 定められた量の範囲内での排出抑制を図りうると される。規制や課徵金に比し, 排出者の自主的能 動的努力を促す点で市場指向的な方策とされる。 しかし, 現実の実施例としては, 米国の大気清浄 化法改正法における $\mathrm{SO}_{\mathrm{X}}$ 排出抑制等と数が少な く, 余り広範囲に利用されていない。課徴金・割 戻制は，一定基準以上の性能には，報償金を，そ れ以下の性能には課徴金を課するというものであ り，例えば，自動車の燃費改善策の手段として提 案される。この制度が有効に機能するには, いか にして基準值を設定するかが重要である。この他, 空き午等回収策として, 供託制 (deposit) 等が 提案されている。

これ等の方策について，理論的な検討（市場指 向性等) の他, 実施面（実効性確保，体制整備状 況等）の検討も必要であり，既存の制度，機構と の整合性も考慮して決める必要がある。これには, 各国毎に固有な状況も踏まえて判断すべきである。 現実には，具体的手段の適用をどうするべきか, の問題は多い。

例えば，一般的に規則は，介入主義的であり， 税等の市場指向的措置が望ましい。しかし，規則 により早く環境対策に取り組むのと，市場指向的 な制度の導入を待って遅く対策に取り組むのとど ちらが望ましいか。これは日本と米国の環境問題 への取り組み方の差異を示したものであるが，結 果的に，日本が間違っていたとも言えない，とも 考える。また，このように市場指向的米国でも， 最近の電力等公益事業に扔いて, 需要管理策 (DMS) の推進のために，州の公益事業規制委 員会が料金算定段階で「総合資源計画」 
(Integrated Resource Planning, IPR) と呼ぶ, 各 種の環境費用を含めていわば行政指導で外部費用 を事実上折り込むやり方をしている。これには， 立法手続を経ないで, 恣意的に価格を歪曲する恐 れがある，という批判がある。このIPR を含む DMS は，米国のみならず，途上国においても導 入が試みられている。エネルギー利用が非効率で あり，価格設定が市場原理を完全に反映しない国 が多いので，エネルギー需要の効率改善に着目す る長所と価格の歪みを必ずしも是正しない危険と の比較の重要性は, 米国の場合以上に, 大きい。

各国共通の気候温暖化対策として, 炭素税の導 入が提案されているが，この導入状況は，IEA 資 料によれば, 表 5 の通りである。共通点としては, 他の税の見返り減税等で価格への影響も余り大き くない, 税率が高率でないこと, 一部の産業への
適用を除外したり，軽減したりしていること等が 挙げられる。どの位の課税でどの位炭酸ガスの排 出が抑えられるかについては, IEA 展望は, 1993 年から段階的に, OECD 地域でそれぞれ炭素 $\mathrm{t}$ 当 り100ドルおよび300ドルに導入した場合を想定し た推計を行った。OECD の2010年の排出量は，基 準ケースに比し，100ドルの場合で，9％減の $3,300 \mathrm{t}, 300$ ドルの場合で $17 \%$ 減の $2,990 \mathrm{t}$ となり, いずれも1990年の水準 $(2,830 \mathrm{t})$ を上回る。税額 を 3 倍にしても, 減少量は倍増に止まる。また, 地理的にみると, 北米では, 1990年レベルに近く, 欧州では, やや高く, 太平洋では $13 \%$ 高い。この 結果から, 現状において, 相当高率の炭素税を課 しても，炭酸ガスの排出量を大きく下げることは 難しく, また, 国, 地域により, 反応が異なると いえる。

表 5 OECD 諸国の炭素税導入

\begin{tabular}{|c|c|c|c|c|c|}
\hline 国 名 & 税率(炭素t 当りドル) ${ }^{1)}$ & 対象燃料 & 除 & 燃料価格への影響 & \\
\hline デンマーク & $\begin{array}{l}\text { 家庭 } 15.9 \\
\text { 産業 } \quad 7.9\end{array}$ & $\begin{array}{l}\text { 家庭 石炭・石油 } \\
\text { (除ガソリン)電気 } \\
\text { 産業 石炭・石油 } \\
\text { (除ガソリン)電気 }\end{array}$ & $\begin{array}{l}\text { 産業 (エネルギー } \\
\text { 集約型産業向条件 } \\
\text { 付の払戻し) }\end{array}$ & $\begin{array}{ll}\text { 家庭 } & \text { 石炭 }+5 \% \\
& \text { 電気 }+3 \% \\
\text { 産業 } & \text { 石炭 }+16 \% \\
& \text { 電気 }+12 \% \\
& \text { 燃料 }+18 \% \\
& \text { 油 }\end{array}$ & $\begin{array}{l}\text { 総合炭酸ガスエネ } \\
\text { ルギー課税の一環 } \\
\text { として導入 }\end{array}$ \\
\hline フィンランド & 6 & 燃料用 & $\begin{array}{l}\text { 産業用原料 - 外航 } \\
\text { 船舶 - 航空機用燃 } \\
\text { 料 }\end{array}$ & $\begin{array}{l}\text { 電気, 軽燃料油, } \\
\text { 天然ガス }+1-2 \% \\
\text { 石炭・ガソリン・ } \\
\text { 重油 } \quad+5-8 \% \\
\text { 軽油 } \quad+10 \% \\
\end{array}$ & $\begin{array}{l}\text { 然料油へは炭素含 } \\
\text { 有量比例よりは重 } \\
\text { い税率となってい } \\
\text { る }\end{array}$ \\
\hline オ ラン ダ & $\begin{array}{l}9.4\left(\mathrm{CO}_{2} \text { 部 分 } の ~\right. \\
\text { み })\end{array}$ & $\begin{array}{l}\text { 化石燃料(産業用 } \\
\text { 料ガスを含む) }\end{array}$ & $\begin{array}{l}\text { 非エネルギー使用 } \\
\text { および外航船舶・ } \\
\text { 航空機用燃料 }\end{array}$ & $\begin{array}{lr}\text { 交通用 } & \text { 軽微 } \\
\text { その他 } & 10-15 \%\end{array}$ & $\begin{array}{l}\text { 従前の環境税の改 } \\
\text { 正 }(50 \% \text { 炭酸ガス, } \\
50 \% \text { エルル゙ー基 } \\
\text { 準) }\end{array}$ \\
\hline ノルウェー & $\begin{array}{c}180 \text { (ガソリン) } \\
81 \text { (軽油) } \\
180 \text { (天然ガス) } \\
57-85 \text { (石炭) } \\
\end{array}$ & $\begin{array}{l}\text { 石油製品・天然ガ } \\
\text { ス・石炭 }\end{array}$ & $\begin{array}{l}\text { 船舶 - 航空機用燃 } \\
\text { 料 } \\
\text { 産業原料用石炭 }\end{array}$ & 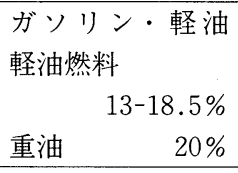 & \\
\hline スウェーデン & $\begin{array}{l}\text { 民生 } 166 \\
\text { 産業 } 40\end{array}$ & $\begin{array}{l}\text { 化石燃料 } \\
\text { 化石燃料 }\end{array}$ & $\begin{array}{l}\text { エネルギー集約産 } \\
\text { 業には炭酸ガス・ } \\
\text { エネルギー税支払 } \\
\text { 上限設定, 電力・ } \\
\text { 外航船舶・バイオ } \\
\text { 然料・エタノール }\end{array}$ & $\begin{array}{l}\text { 民生用 +5-13\% } \\
\text { 産業用 + } 25-40 \%\end{array}$ & $\begin{array}{l}\text { 1993年は産業部門 } \\
\text { およびエタノール } \\
\text { にはエネルギー税 } \\
\text { 免税 }\end{array}$ \\
\hline
\end{tabular}

1） 1993年第 1 四半期の為替レート

出 所: IEA Energy Environment update, 9 August 1993 


\section{4. 対応策のあり方}

エネルギー対策として環境に配慮して，今後の エネルギー需要の増加に対応していくためには, 省エネルギーと代替エネルギーの推進が必要とな る。前述のように, 気候温暖化問題対策としての 直接的な脱炭酸ガス手段で, エネルギー効率と費 用両面を満たすものは, 現在ない。脱硫・脱硝技 術もエネルギー効率を低下させるが，その効率低 下をさらに, 補う効率改善が達成されてきている。 しかし, 省エネルギー技術と非化石燃料への転換 技術で完全に地球環境問題を含む現在の環境問題 を一挙に解決することはできない。

まず，第 1 に技術的な限界がある。ボイラー等 の燃焼効率が向上しているとはいえ，40\%をやや 上回っているに過ぎない。関連技術の制約もある。 例えば，実用的な電気自動車の開発も軽量・小型 の蓄電池の開発が課題である非化石燃料について, 石油資源ほど偏在してないが，資源の制約もある。 発電に利用しうる水力資源も多くは遠隔地である 等の制約がある。太陽光も, 日照条件等に左右さ れる。

第 2 に, 経済的制約もある。石油価格等からみ て，競争できる代替エネルギーや省エネルギーの 可能性は, 限られている。これは, 市場に歪みが あったりする場合は，一層甚たしい。

第 3 に, 非化石燃料が経済的に競争し競争しえ ても，市場で受容されるための条件が整わないこ ともある。例えば，非化石燃料も様々の環境的制 約がある。原子力発電所の事故に伴う放射能漏れ の恐れだけでなく，薪等も伝統的燃焼の仕方では， 空気污染による健康被害を生んできた。制度, 慣 行が障壁となることもある。

このような制約条件は，各国により異なること もある。例えば，産油国のノルウェーは，発電を ほぼ水力発電で賄っている。資源の少ないフラン スでは，原子力と水力で発電の殆どを賄っている。 IEA 統計では, 中国の一次エネルギー供給の 8 割 近くが石炭である。従って, 非化石燃料への転換 も各国毎にその可能性は異なる。同様に, エネル ギー効率化についても, IEA 統計でみると, 産業 部門の最終エネルギー消費に占める比率は, 中国 では $65 \%$ と高く, 日本で $46 \%$, 米国で30\%, 交通 部門は，それぞれ，5\%，24\%，35\%となり，対
策の重点の置き所が異なる。

1973年以降の各国のエネルギー需給の動向をみ ても, 省エネルギーと非化石燃料との組合せは, 国により異なる。これを，これまでのエネルギー 関連炭酸ガス排出量抑制の関連でみると, フラン スは，原子力発電の役割が大きく，米国は，省工 ネルギーの役割が多かった。

個々の対策技術（燃焼技術等）では，同じ様な 改善の展望があっても, 対応の組合せの選択は, 一様ではない。このことは, 各国間で一率の効率 的改善を目指すことの非現実性も示唆している。

他方, 現実に, 現存の技術的可能性, 経済的可 能性のある技術的対応策が未利用の侭残っている ことも事実である。さらに, 単に, 炭酸ガス排出 抑制だけでなく，他の環境目標等をも満足しうる 対策もある。このように, 他の対策目標からも正 当化されるような対策を，「後悔のない（no -regrets)」対策といったり，「一挙両得（win -win)」戦略という。このような対策を着実に推 進するには，市場の価格の歪みを是正すると共に， 合意の存在する分野から外部性を内部化すること が必要と考える。

さらに，新技術の開発，普及も重要である。日 本では, 1990年に, 超長期的な技術の逐次的展開 と普及の重要性を訴えて,「地球再生計画」の概 念を提示し，その考えに沿った，国際協力を進め ている。また, 途上国の開発戦略と関連し, 途上 国は，既存の技術インフラスラクチュアの制約に とらわれない点を活かし, 先端技術の成果を取り 入れていく (technology leap frogging) を提案す る意見もある。例えば，GNP当りの趨勢をみる と, 山型の曲線を各国が描くが後発国ほどその頂 が低くなる傾向があり（図1)，これがその例示 とされる。

この “leap frogging”については, 自然発生的な ものではなく, 途上国における制度改革, 学習能 力の向上等受入条件の整備なしには成功しないと いう意見もある。

また，今後のエネルギー需給を考えるには，供 給面よりも需要面が重要で, ライフスタイルの変 革が必要という意見もある。そのような意識改革 には, 教育も重要となるが, 環境費用の適切な内 部化により，エネルギー価格に反映させて，消費 


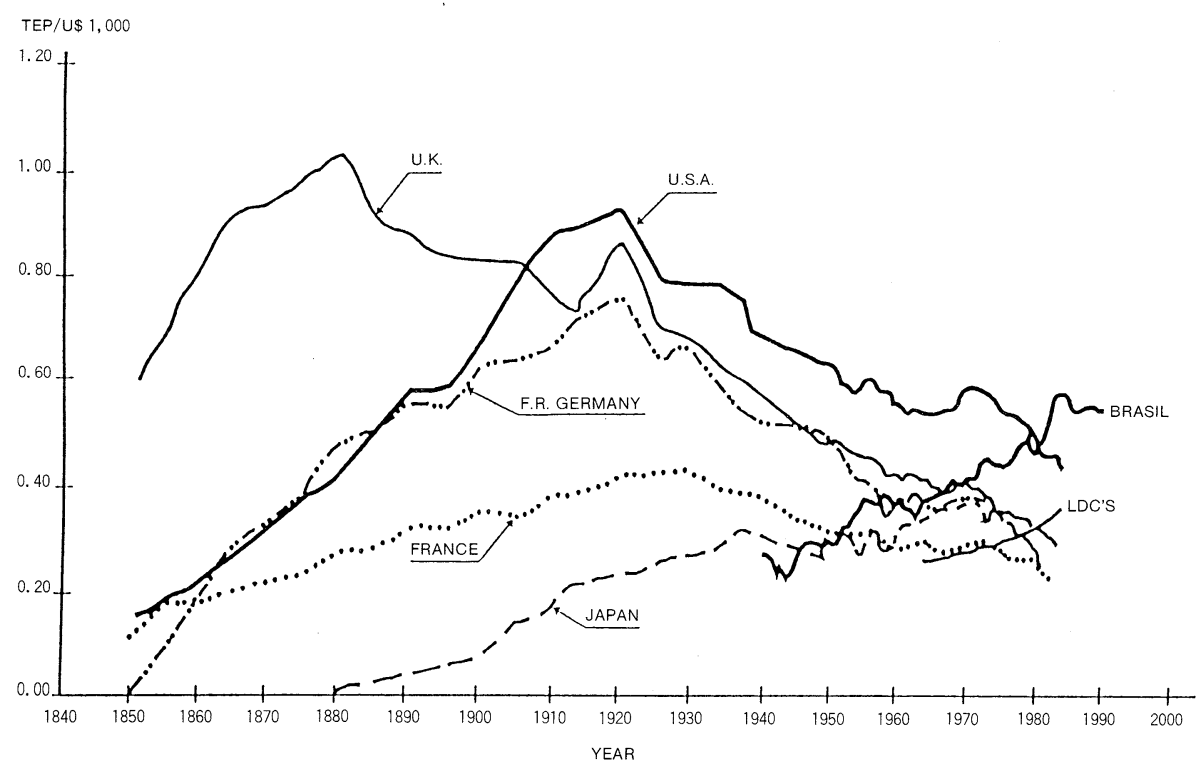

出＼cjkstart所 : José Goldemberg : [1993] Leap frogging for Developing Countries, Paper Submitted for the Tokyo Conference on Global Environment organised by the United Nations University and International Development Center of Japan. 25-27 October, 1993

\section{図 1 エネルギー原単位の趨勢}

者に選択をさせる過程で進めてくことも必要では ないか, と考える。

\section{5. 結 論}

今後の経済発展を確保するとともに，環境の保 全・改善を考えたエネルギー需給のバランスを確 保することは，人類共通の課題である。このため には，長い目で見ながら着実な対応を進める必要 があるが，それには，技術の開発，普及のみなら ず，価格の歪みを無くし，環境保全その他の外部 費用を適切に内部化する等が，求められている。 また，このような対応については，各国の置かれ ている異なる状況を考慮して, 多様な取組となら ざるを得ない。

\section{参考文献}

1) World Meteorological Organization/United Nations Environmenta Programme, Intergovernmental Panel on Climate Change, Climate Change: The IPCC 1990 and 1992 Assessments, 1992

2) World Energy Council, Energy for Tomorrow's World-the Realities, the Real Options and the Agenda for Achievement, 1993, St. Martin's Press, New York

3) International Energy Agency, World Energy Outlook, 1993, Paris 


\title{
World Trends in Energy and Environment
}

\author{
Keiichi YOKOBORI \\ $\left(\begin{array}{c}\text { Organizing Committee, 16th Congress, } \\ \text { World Energy Council (WEC, Tokyo, 95) }\end{array}\right)$
}

SYNOPSIS : - The economic development since the Industrial Revolution has been supported by the provision of energy, which has also increased the burden on the environment. While the industrialised countries account for the large proportion of the past and present energy consumption and environmental pollution, the contribution from the nations which are presently called "developing countries" is expected to exceed half the global energy requirements and environmental pollution in 30 years with their economic development. In addition, the environmental concerns have extended from the traditional and localised pollutions to those with wider time and regional perspective, called the global environmental problems such as climatic warming. The future task of the human kind is to ensure the stable energy demand and supply and to improve the environment, while allowing the economic progress. At the same time, the country and regional differences exist in their energy resource endowment, response potential to environmental protection, and other characteristics. Thus, the steady actions are needed, reflecting the specific circumstances, mutually learning other countries' experiences and exchanging technologies and information. The short-sighted uniform measures, such as the introduction of the common carbon tax would be counter-productive.

\section{Key Words}

Energy outlook, Energy and environment, Global environmentonal issues, Internalisation of externalities 